\section{THE MANUFACTURE OF VARIETIES OF} COMMON SALT.

GREAT interest has been aroused among salt manufacturers by the announcement of the discovery of a new process capable of producing every variety of commercial salt in one plant and with great economy of fuel. The inventor is $\mathrm{Mr}$. James Hodgkinson, of the firm of James Hodgkinson, Ltd., Pendleton, Manchester, makers of mechanical stokers. It is said that the patent rights for America have been sold to an American syndicate for $\mathbf{r}, \infty 00,000 l .$, and to the Canadian Pacific Railway Company for Canada.

Up to the present time, salt has been manufactured by a process scarcely different from that used during the Roman occupation, namely, boiling down the brine in shallow open pans heated by coal fires. It is true that in I839 Reynolds introduced the use of closed pans, in which the steam was passed from the first pan to the others, and a considerable economy in fuel effected, one ton of coal yielding four tons of salt, as against two tons in the case of open pans, which, however, still continued in use.

The chief features in the Hodgkinson process are the introduction of mechanical stokers for the fires, and the working of a plant consisting of seven pans, three closed and four open, heated by one fire. The quality and size of the salt crystals largely depend on the temperature, which can be so regulated in the new process as to produce every kind required.

The first pan is covered, and produces, by crystallisation alone, a table salt so fine that no grinding is required. From this pan proceed waste gases, which pass underneath and heat all the remaining pans, while the steam passes over to the succeeding pans and assists the precipitation of the salt. The second and third pans are also covered, and produce a slightly coarser variety, known as " dairy" salt. In the succeeding pans, all of which are open, the gases are at a lower temperature, and coarser salt in larger crystals is obtained. This is known as "fishery" salt, and is used in fish-curing. It should be added that there is an automatic flow of brine into the pans, and an automatic discharge of the salt produced.

The process, first successfully tried at Northwich, then extended to Port Sunlight and St. Helens, has resulted in such complete consumption of smoke that several large chimneys have been dispensed with. The success of the process must be assured if the hopes of the inventor are realised in practice. He claims that four or five times as much salt can be produced in a given time as compared with the old process, and that three tons of coal will be saved out of every four.

ARCHAOLOGICAL RESEARCH IN ARKANSAS. ${ }^{1}$

$M R$. CLARENCE B. MOORE has issued another of his valuable memoirs on the prehistoric pottery of the United States. His last season's field work was on the St. Francis, Little, White, and Black rivers in Arkansas. Like all his other memoirs, this one is illustrated with maps and very numerous beautiful illustrations, many in colours, and all of large size, so that every detail is visible. Mr. Moore is still in the collecting stage of his work; generalisations we may expect at a future time. The principal sites along the St. Francis, although, as a rule, having mounds in connection with them, are in reality great dwelling-sites which have increased in height gradually through long periods of occupancy, and the aborigines, burying where they lived, have formed in course of time great cemeteries, all of which he believes to be pre-Columbian, since no object was found in any way indicating intercourse with Europeans excepting a bone comb, which, "though the shape is undoubtedly copied from a European model, the decoration points to Indian workmanship"; he asserts it is prehistoric.

The St. Francis valley has yielded more examples of its ware than has any equal area in the United States, and has been largely exploited by irresponsible collectors. The earthenware is shell-tempered. Quantity rather than quality seems to have been the aim of its makers, for the

1 Journal of the Academy of Natural Sciences of Philadelphia. 2nd series, vol. xiv., part 2: "Antiquities of the St. Francis, White, and Black Rivers, Arkansas," by C. B. Moore, pp. 255-364 (Philadelphia, 1910).

NO. 2 I.58, VOL. 86$]$ ware is often insufficiently fired, and the vessels are frequently thick and lop-sided. A high polish is almost absent. A very large proportion of the vessels are undecorated or with trivial decoration. Incised decoration is scarcely ever seen, the inferior surface of most of the ware being unsuited to incised decoration of excellent quality, even had it been attempted. Practically none of the vessels obtained by him are of types new to the pottery of the Middle Mississippi valley. The types of pottery have been well described by Prof. W. H. Holmes in his "Aboriginal Pottery of the Eastern United States" (2oth Ann. Rep. Bur. Am. Eth). The most noteworthy find was a ceremonial "spear-head" of sheet-copper. Several vessels in the form of heads with fairly well-modelled faces were obtained, and some in the form of human figures. One burial of a very young infant had near by it a small bowl in which, upright, was a little effigy bottle.

Unlike the St. Francis river sites, which are on high ground, the sites on the White river and its upper reaches, the Black river, are on low, overflow ground, where archæological research is not likely to be rewarded; indeed, with a few trifling exceptions, no aboriginal objects had previously been obtained from this district. With one exception, no site of interest was found along the White river, and but three vessels of earthenware were encountered along the stream. Along the Black river, while some vessels were found, not one was of a character to warrant its transportation home. Although burials were fairly numerous, they were almost invariably unaccompanied by artifacts, a remarkable fact considering the custom of lavishing deposits upon the dead as practised by aborigines of neighbouring regions. The best find was a narrow, well-made ceremonial axe-head of green quartzite, $212 \mathrm{~mm}$. in length.

A. C. Haddon.

THE COEFFICIENT OF SKIN FRICTION IN AIR AT MODERATELY HIGH VELOCITIES.

THE object of this study is to find a coefficient of turbulent friction readily applicable to the design of aërodynamic appliances such as aëroplanes and windmills.

It is assumed throughout that:-

(I) The surfaces on which the friction occurs are of reasonably smooth finish, and present no marked head resistance due to irregularities of surface.

(2) The velocities of the air relative to the surface are well above the critical values at which pure viscous shearing resistance is superseded by the generation of momentum in the contacting film or fluid, so that the skin resistance varies as the square of the velocity.

(3) The length of the surface in the direction of motion bears so small a relation to the dimensions perpendicular thereto that the diminution of the coefficient with the length is inappreciable.

The study is divided into two parts :-

(a) An analysis of the various methods of determining the skin-friction coefficient already known, with a tabular record of the numerical results already attained or thereby deducible, leading up to the most probable value of the said coefficient.

[(b) An experimental study made with the purpose of confirming the accuracy or otherwise of the said probable value. This is now in progress, the apparatus (an epicyclic differential dynamometer) being made. As this will not be ready for some considerable time, it may be useful to publish the comparative analysis beforehand.]

\section{Symbols Employed.}

British engineer's units-Pounds, feet, seconds. Force in Ibs. wt.

$f$. Coefficient of skin friction.

$\mathrm{C}=$ about 0.7 , being the coefficient of normal pressure on unit square surface, with unit velocity, and unit mass of air.

$\rho$. Mass of unit volume of air at normal temperature. About 0.08 pound per cubic foot.

$\mathrm{A}_{1}$. Area subiect to skin friction.

$\mathrm{A}_{2}$. Area of mid-section or normal surface of a dirigible.

$k$ : Ratio of skin friction on a dirigible to normal resistance on an area equal to the cross-section. 